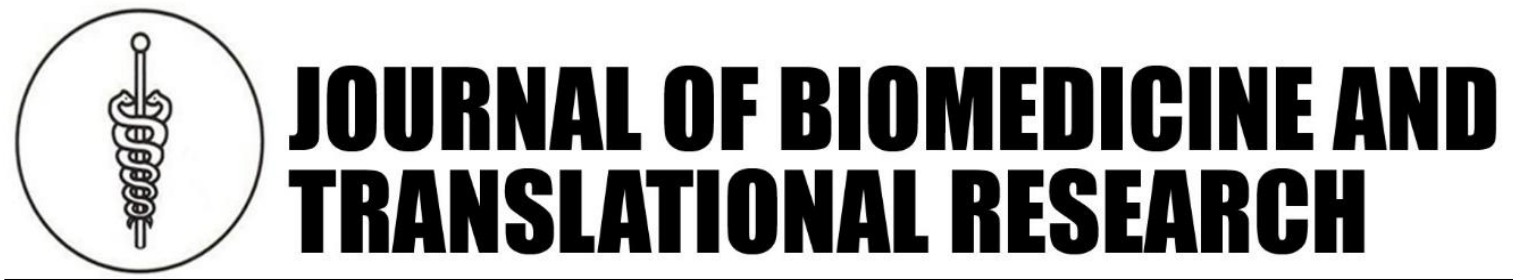

Copyright $@ 2018$ by Faculty of Medicine Diponegoro University and Indonesian Medical Association, Central Java Region

\title{
Marfan syndrome, a review
}

\author{
Gerard Pals PhD \\ Dept. Of Clinical Genetics, Amsterdam University Medical Centers, De Boelelaan 1117, Amsterdam, The \\ Netherlands
}

\section{Article Info \\ History:}

Received: 07 Nov 2018

Accepted: 09 Nov 2018

Available: 31 Dec 2018

\begin{abstract}
Background: Marfan syndrome is an inherited condition, that affects many organ systems. The most obvious features are the skeletal abnormalities: tall stature, long limbs, arachnodactyly (spider hands). Ocular symptoms include severe myopia and lens luxation. The clinically most severe symptoms are cardiovascular: mitral valve insufficiency, aortic root enlargement and thoracic aortic aneurysms and dissections. Marfan syndrome is usually inherited in an autosomal dominant fashion, but in some families a recessive mode of inheritance has been described. Most cases are caused by mutations in the FBN1 gene. The phenotype is highly variable, also within families. The absence of the skeletal symptoms often leads to a failure to recognize the syndrome. The prevalence of Marfan syndrome is estimated to be 1 in 2500 , in all populations, including Indonesia. There is some controversy in the literature regarding the involvement of transforming growth factor beat (TGF $\beta$ ) in the etiology of Marfan syndrome, due to the fact that phosphorylation of the signal molecules $\operatorname{smad} 2$ and smad 3 in some publications has been wrongly interpreted as exclusively caused by TGF $\beta$, which is only one of the many ligands that can induce $\operatorname{smad} 2 / 3$ phosphorylation.

Clinical trials, testing the effect of losartan on aortic root dilatation and the growth of aneurysms, have shown conflicting results. In one study, the effect of losartan was only found in a subgroup of patients with a specific type of mutations, that lead to reduced amount of normal fibrillin 1 protein (haploinsufficiency). The distribution of this type of mutations in different population may explain the conflicting results of the trials.
\end{abstract}

Keywords: Marfan syndrome; FBN1; aortic aneurysm, losartan.

Permalink/ DOI: https://doi.org/10.14710/jbtr.v4i2.3560

\section{INTRODUCTION}

Marfan syndrome is named after the French pediatrician Antoine Bernard-Jean Marfan who described in 1896 a girl with arachnodactyly and long limbs ${ }^{1}$. The patient also had congenital contractures of the elbows and would not fulfill the current criteria for Marfan syndrome. She probably was suffering from a condition that we now call Contractural arachnodactyly, caused by mutations in the FBN2 gene.

The clinical features of Marfan syndrome affect many systems of the body. The most obvious are the skeletal features, long limbs, tall stature, long thin fingers (arachnodactyly or spider fingers). The skeletal features can be scored objectively as: arm span more than $1.05 \mathrm{x}$ body length; wrist sign (thumb and index finger can encircle the wrist of the other hand with at least one digit overlap) and thumb sign (when making a fist around the thumb, one digit of the thumb sticks out). The main neurological symptom is dural ectasias. The most severe symptoms are cardiovascular: mitral valve prolapse, aortic dilatation and thoracic aortic aneurysms and dissections, which may lead to sudden death $^{2}$. However, I noticed in discussions with patients that they often consider the ocular symptoms, severe myopia and lens luxation, the worst for themselves, because the latter may lead to blindness. 
It is important to realize that the obvious skeletal features are not always present. Within families we often see carriers of the same pathogenic mutation, that have very different phenotypes ${ }^{3,4,5}$. This means that Marfan syndrome can be present without the typical "Marfan habitus". The multitude of symptoms have led to defining clinical criteria for Marfan syndrome, named the Berlin nosology ${ }^{6}$, Ghent criteria ${ }^{7}$ and the revised Ghent nosology or criteria ${ }^{8}$, named after the symposia where the criteria were formulated and discussed. In the revised criteria, the major and minor criteria were replaced by a scoring system. Dural ectasias play a less important role in the criteria, because they are also very common in non-Marfan patients $^{8,9}$. In Asian Marfan patients, the phenotype is different from patients with a European background $^{10,11}$, so the criteria may have to be adapted for the Asian population.

One of the most important criteria for Marfan syndrome nowadays is the presence of a pathogenic mutation in the FBN1 gene. However, assessing the pathogenic effect of DNA variants is not a simple matter, as will be discussed below. Mutations in FBN1 have also been demonstrated in patients that do not meet clinical criteria for Marfan syndrome ${ }^{12}$. The first mutation in FBN1 found in Marfan syndrome was published in $1991^{13}$. There is still discussion on the subject of locus heterogeneity, but it is clear that the majority of Marfan syndrome patients have a pathogenic variant in the $F B N 1$ gene ${ }^{14,15}$. In many countries, however, genetic testing is not readily available, so the use of the clinical criteria remains important in assessing Marfan syndrome and related phenotypes $^{16,17}$.

In most cases, Marfan syndrome is inherited in an autosomal dominant fashion. However, autosomal recessive inheritance of mutations in FBN1 has also been demonstrated and should be taken into account in genetic counseling ${ }^{18,19}$.

\section{THE PROTEIN}

The fibrillin 1 protein is a glycoprotein and is an important constituent of the elastic fibers in the large blood vessels (www.uniprot.org/uniprot/P35555). Fibrillin is important for tensile strength, whereas elastin is important for elasticity and extensibility. Consequently, the ratio of fibrillin and elastin has a large impact on the properties of the vessel wall. The cells that produce these structural proteins have no possible way of determining the amount of protein that has been produced, so the production of the proteins is not subject to any feedback regulation. Consequently, the gene dosage effect is very strong and null-alleles of the encoding genes have a strong effect on protein production and the ratio between elastin and fibrillin.

Apart from a function in structural properties of the vessel wall, fibrillin is also important as docking site for a number of inactive protein complexes, such as the latent TGF- $\beta 1,-2$ and $-3^{20,21}$ and several matrix proteases, such as ADAMTS10 and ADAMTS17 ${ }^{22}$. So fibrillin plays an important role in regulating the bioavailability of these growth factors and proteases. Other proteins that bind to fibrillin 1, such as the glycoproteins ADAMTSL2 and ADAMTSL4 probably play a role in fibril formation ${ }^{22,23}$.

The fibrillin 1 protein has many repeated motifs (figure 1). The most common motifs are the epidermal growth factor-like domains (EGF-like domains). There are 47 EGF-like domains, 44 of these are calciumbinding and 3 are non-calcium binding. Other repeated domains are the seven 8-cys domains (containing 8 cysteine residues) and the two hybrid domains. Most of these domains function as docking sites for other proteins, as mentioned above. The loss function of these binding site probably leads to Mafan syndrome symptoms, but no clear genotype-phenotype correlations have been described, except for the domains involved in Weill-Marchesany syndrome or ectopia lentis $^{22,22}$.

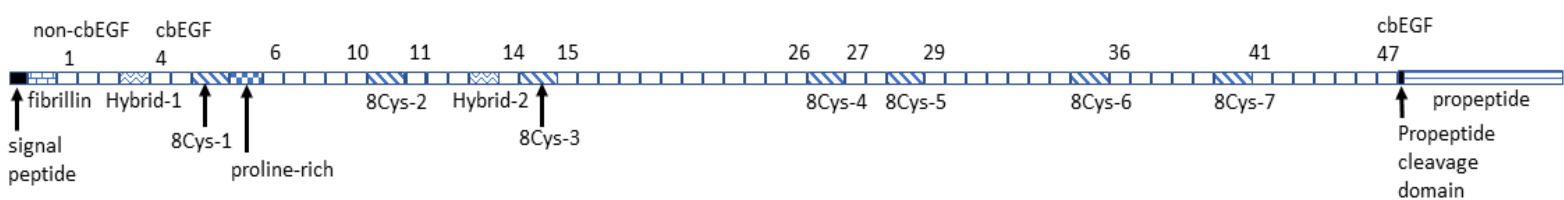

Figure 1. Functional domains in fibrillin 1. cbEGF = calcium binding EGF-like domains. The signal peptide and propeptide are removed during transport and fibril formation. The domains are drawn to scale.

\section{THE FBN1 GENE}

The FBN1 gene is a very large gene, consisting of 65 coding exons and one non-coding 5'exon, that cover 237,482 nucleotides of genomic DNA and encode a messenger RNA of 8616 coding nucleotides, 395 5'UTR and 2684 nucleotides 3'UTR. The FBN1 gene has a single large translated transcript (www.ensemble.org). We refer to transcript NM_000138.4 in this paper, when describing DNA variants on the cDNA.

\section{VARIANTS IN FBN1 AND THEIR INTERPRETATION}

Since the publication of the first mutation in $F B N 1$, pathogenic DNA variants have been found in all 65 coding exons of this gene, which reflects the structural and docking functions of fibrillin 1 , that can be disturbed by changes almost anywhere in the protein. This is also apparent from the extremely high level of evolutionary sequence conservation of fibrillin 1 (Figure 2). In our diagnostic laboratory at Amsterdam University medical centers, 869 unique pathogenic DNA variants have been found in FBN1. Some $65 \%$ of 
these mutations are missense mutations, that usually have a dominant effect, because the aberrant protein is incorporated in the extracellular matrix (ECM) and disturbs structure and function of the fibrils and interactions with other proteins. disulfide bridges, that determine the three-dimensional structure of these domains (figure 3 ). Therefore, the missense mutations involving loss or gain of a cysteine in these domains are considered to be pathogenic. The same can be said for the 8-cys and hybrid domains.

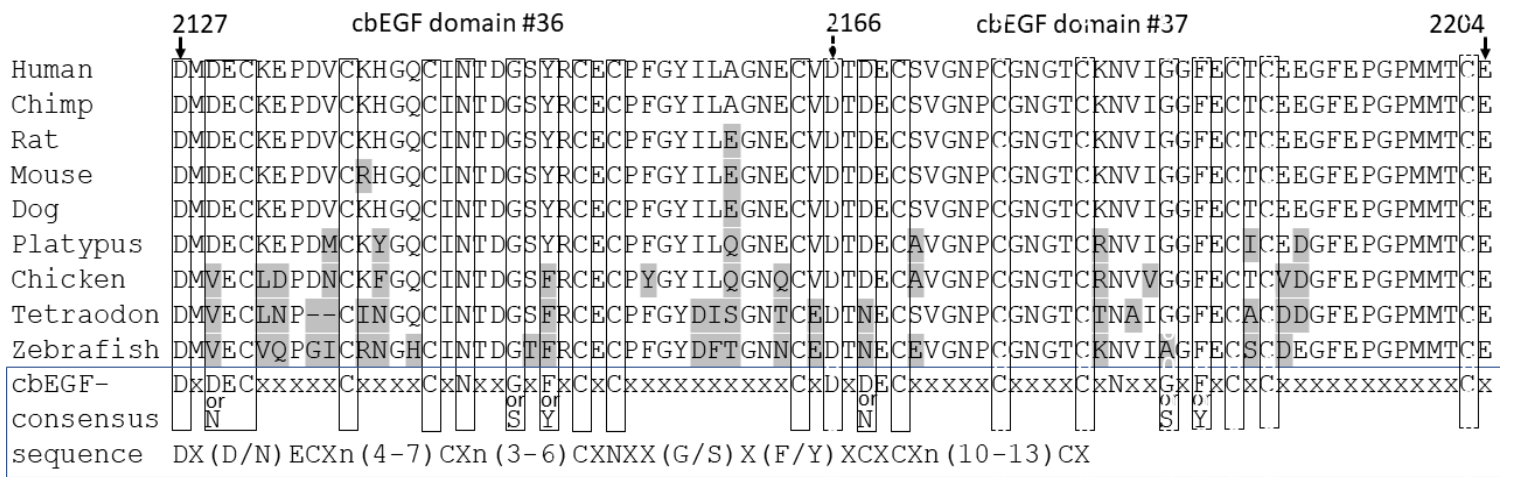

Figure 2. Example of evolutionary sequence conservation of the fibrillin 1 protein, using single letter amino acid code, showing cbEGF domains \#36 and \#37. Differences are marked with grey background. The proposed cbEGF consensus sequence is shown at the bottom. The essential amino acid residues in the consensus sequence are boxed. The numbers at the top refer to amino acid residues in the protein sequence.

The international database lists 1847 unique variants in FBN1 (http://www.umd.be/FBN1/) ${ }^{24}$. Mutations in FBN1 range from single base substitutions to large genomic deletions or duplications ${ }^{25,26,27,28}$. Only $1.7 \%$ of the records in the database show large deletions or duplications ( $\geq 1$ exon), whereas In our laboratory, $12 \%$ of the pathogenic mutations are large deletions or duplications. This probably reflects the fact that our lab, as co-developers of the multiplex ligation dependent probe amplification (MLPA) ${ }^{30}$ technique that is used to detect this type of mutations, has tested all patients. Deletion of the entire gene is a recurrent and not a founder mutation, because deletions of different lengths, ranging from $1 \mathrm{Mb}$ to $10 \mathrm{Mb}$, have been found in different families. Only the largest deletions were associated with additional features in the phenotype, such as mental retardation ${ }^{25,29}$.

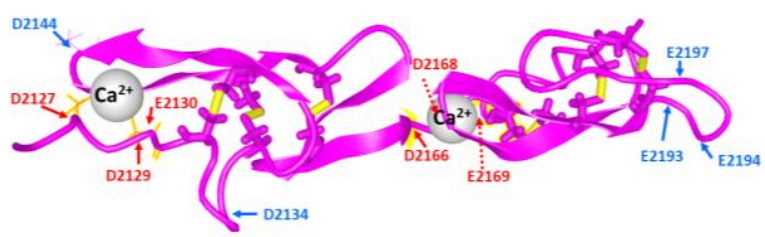

Figure 3. Three dimensional representation of cbEGFdomains \#36 and \#37, created by $\mathrm{iCn} 3 \mathrm{D}^{31,32}$. Disulfide bonds (yellow bars) and negatively charged amino acid residues are indicated. $\mathrm{D}=$ aspartic acid; $\mathrm{E}=$ glutamic acid. The N-terminal acidic residues of each domain are involved in calcium binding and are shown in red. Other negatively charged residues are shown in blue. These are pointed outward and are probably involved in interactions with other proteins.

The large number of missense mutations (65\%) makes interpretation of variants difficult. In some cases the conclusions are not complicated. For example, in the EGF-like domains, the six cysteine residues play an important role in the formation of intramolecular three
Unfortunately, in the publication concerning the revised Ghent criteria (Dietz et al. 2010), the paragraphs about mutation interpretation contain several errors, which will lead to false assumptions about the pathogenic or benign effects of variants. For example, the consensus amino acid sequence motif of the EGF domains is incorrectly represented as: $((\mathrm{D} / \mathrm{N}) \mathrm{X}(\mathrm{D} / \mathrm{N})(\mathrm{E} / \mathrm{Q}) \mathrm{Xm}(\mathrm{D} / \mathrm{N}) \mathrm{Xn}(\mathrm{Y} / \mathrm{F})$ with $\mathrm{m}$ and $\mathrm{n}$ representing variable numbers of residues; $\mathrm{D}$ aspartic acid, $\mathrm{N}$ asparagine, $\mathrm{E}$ glutamic acid, $\mathrm{Q}$ glutamine, $\mathrm{Y}$ tyrosine, $\mathrm{F}$ phenylalanine). This would mean that the first amino acid residue can be either aspartic acid (D) or asparagine $(\mathrm{N})$ and the fourth residue can be either glutamic acid (E) or glutamine (Q), whereas in the calcium binding EGF-like domains, the first and fourth amino acids are always the negatively charged aspartic acid and glutamic acid. These residues are $100 \%$ conserved in all 44 calcium binding EGF domains of fibrillin 1 . These negatively charged residues play an essential role in binding of the positively charged calcium ions, $\mathrm{Ca}^{2+}$, that are necessary for stabilization of the protein as has been shown by NMR analysis and $3 \mathrm{~d}$-imaging (figure 3 ) $^{31,32}$. In Marfan patients the effect of mutations of the first aspartic acid of cbEGF domains has been shown by Hilhorst et al. ${ }^{33}$ The position and relative distance of the cysteine residues is also an essential feature of the EGF domains. The consensus amino acid sequence of the calcium binding EGF domains should be represented as:

\section{$\operatorname{DX}(\mathrm{D} / \mathrm{N}) \mathrm{ECX}_{\mathrm{n}(4-7)} \mathrm{CX}_{\mathrm{n}(3-6)} \mathrm{CXNXX}(\mathrm{G} / \mathrm{S}) \mathrm{X}(\mathrm{F} / \mathrm{Y}) \mathrm{XCXCX}_{\mathrm{n}(10-13)} \mathrm{CX}$,}

where $\mathrm{D}$ is aspartic acid, $\mathrm{N}$ is asparagine, $\mathrm{E}$ is glutamic acid, $\mathrm{C}$ is cysteine, $\mathrm{G}$ is glycine, $\mathrm{S}$ is serine and $\mathrm{X}$ is any amino acid residue and $\mathrm{n}$ is a number in the indicated ranges. Any deviation from this consensus sequence should be considered pathogenic.

Another doubtful point in the publication of Loeys et al. ${ }^{8}$ is this: "Other missense mutations: segregation 
in family if possible + absence in 400 ethnically matched control chromosomes, if no family history: absence in 400 ethnically matched control chromosomes." The problem here is the threshold. For a dominantly inherited mutation it can be assumed that a carrier frequency in the population of $>0.1 \%$ can be considered as evidence that the variant is not pathogenic. Probability calculation tells us that testing of 400 ethnically matched controls, a variant with a frequency of $0.1 \%$ can be found with a probability of $1-0.999^{\wedge} 400=0.33$, or $33 \%$ chance of finding a variant with a population frequency of $0.1 \%$ in 400 control samples. Moreover, the presence of undiagnosed Marfan syndrome patients in the control population cannot be excluded, so even if a variant is found once in the control samples, it is still not clear weather that is evidence of a non-pathogenic variant.

Furthermore, the most common recurrent pathogenic mutation, deletion of the entire FBN1 gene $^{25}$, is not mentioned by Loeys et al. ${ }^{8}$ nor are multiexon deletions and duplications. pathogenic nature of a variant, absence of the variant in the databases or in control samples cannot be used as conclusive evidence for pathogenic variants. On the other hand, presence of a variant at low frequency $(<0.001)$ in the databases is not conclusive evidence of a benign variant.

\section{INDONESIAN MARFAN CASES}

When discussing Marfan syndrome with MD's in East Asian countries, I always hear that Marfan syndrome is extremely rare in East Asia. However, I am convinced that Marfan syndrome is very much underestimated in East Asia. As discussed before, in many Marfan families it is clear that within the families, not all carriers of the same pathogenic mutation have the clearly recognizable Marfan habitus with long limbs and long fingers ${ }^{2,3,4}$. However, they all have the high risk of aortic aneurysms and dissections, often leading to sudden death. The gnomAd (or ExAc) database $^{33}$ contains exome sequences of some 9,000 East Asian individuals without obvious disease.

Table 1. Frequencies of pathogenic (class 5) and likely pathogenic (class 4) variants in FBN1 in East Asian DNA samples, according to the Exome Aggregation database ${ }^{34}$. MAF is minor allele frequency. A MAF of $0.0178 \%$ means a carrier frequency of 1 in 2800. (cDNA numbers according to transcript NM_000138.4)

\begin{tabular}{|c|c|c|c|}
\hline Variant (DNA) & Variant (protein) & MAF East Asia \% & Pathogenicity class \\
\hline c.3128A $>\mathrm{G}$ & p.(Lys1043Arg) & 0.0120 & 5 \\
\hline c. $3172 \mathrm{G}>\mathrm{C}$ & p.(Gly1058Arg) & 0.0058 & 4 \\
\hline c.5546A $>\mathrm{G}$ & p.(Asp1849Gly) & 0.0058 & 5 \\
\hline c.8123A $>\mathrm{G}$ & p.(Asn2708Ser) & 0.0640 & 4 \\
\hline & Total & 0.0876 & Class 4+5 \\
\hline & subtotal & 0.0178 & Class 5 \\
\hline
\end{tabular}

In the currently available exome databases, the population frequencies of variants can be easily checked in many populations. The frequencies in these databases are usually given as minor allele frequencies (MAF), which is not the carrier frequency of the variant, because every individual has two alleles, so the carrier frequency of rare variants is close to $2 \mathrm{x}$ the MAF.

In my experience, it is a very common error in the interpretation of mutations to think that it is necessary to look at the frequency in the same ethnic group as the patient, so it is assumed that the online databases cannot be used for patients from a population that is not represented. This is certainly not true for conclusions regarding the benign nature of variants that have a high frequency in ANY population. If, for example, a variant has a frequency of $5 \%$ in the Dutch population, this is sufficient evidence that the variant is NOT pathogenic, because we know that the frequency of Marfan syndrome in that population is nowhere near $5 \%$. If, on the other hand, a new variant in a patient is not found in any of the exome databases, it can still be a common neutral variant in the ethnic group to which the patient belongs, or it can be a rare benign variant. So, the reasoning presented by Dietz et al. when using 400 control samples can only be used for a negative conclusion: if a variant is found in the control group with a frequency of $>1 \%$ this is conclusive evidence of a benign variant. Without additional evidence of
Checking this database for variants in $F B N 1$, shows that the carrier frequency of known pathogenic mutations in the East Asian population is 0.000356, equaling 1 in 2800 individuals. This is a low estimate, because we only looked at variants that have been listed in CLINVAR as pathogenic, so pathogenic mutations that are specific for the East Asian population cannot be seen. The occurrence of 1 in 2800 is very close to the known incidence in other populations and would mean a total of around 100,000 patients in Indonesia. My point here is, that we don't see the patients in East Asian countries such as Indonesia, because no one is looking.

In Semarang five families with clinical features of Marfan syndrome have been tested and 3 pathogenic variants were found, 2 of which were novel (publication in preparation). This shows that 1) Marfan syndrome is found in Indonesia and that 2) unique mutations are indeed present. This supports my thesis that 1 in 2800 is a low estimate.

\section{GENOTYPE PHENOTYPE CORRELATIONS}

Despite the large phenotypic variation within families among carriers of the same mutation, some genotype - phenotype correlations have been found. Neonatal Marfan syndrome, a very severe form which is apparent at birth, is often caused by single exon deletions or exon skipping mutations, or missense mutations in the central part of the protein (encoded by 
exons 24-36) ${ }^{35,36}$. Nearly all exons of FBN1 consist of a multiple of 3 bases, so exon skipping or deletion do not lead to frameshift and nonsense mediated decay (NMD) of the mutant mRNA. This has probably played an important role during evolution, when the gene acquired a large number of almost identical functional domains, that necessitated a continuous reading frame. Truncating mutations and exon skipping or deletion outside exon 24-36 lead to a more severe phenotype than other mutations, probably because the short protein interferes with correct fibril formation ${ }^{37}$. Grouping patients based on effect of the FBNI mutations on the protein resulted in improved genotype-phenotype correlation $^{38,39,40,41}$, with a striking effect on the response to medication ${ }^{42}$, as discussed below. One group was defined as "haploinsufficiency" (HN), with reduced production of normal fibrillin 1 due to deletion of the gene or null allele caused by nonsense mediated decay. The other group was defined as "dominant negative" (DN), which indicates that the production of mutant protein leads to a negative effect on the extracellular matrix.

\section{MEDICATION}

The life-threatening symptoms of Marfan syndrome are the aortic root dilatation and thoracic aortic aneurysms and dissections, which may lead to sudden death. Therefore, prevention of aortic root dilatation and aneurysm growth is the target of developing drug therapy.

Habashi et al. ${ }^{43}$ have shown in a Marfan rat model, that the angiotensin 1 receptor antagonist losartan has a reducing effect on the growth of aortic diameter. This effect was stronger than blood pressure reduction by beta-blockers. It was concluded that losartan has a sideeffect on the TGF- $\beta$ receptors. The involvement of TGF- $\beta$ was based on the finding of increased nuclear phospho-smad2 in a (one!) patient with Marfan syndrome by Loeys et $\mathrm{al}^{44}$, which led to the assumption that increased TGF- $\beta$ activity is the cause of aortic aneurysms in Marfan syndrome and familial thoracic aortic aneurysms and dissections TAAD). This has led to the so-called TGF- $\beta$ paradox in aortic aneurysms. However, in my opinion, the paradox is the result of an extremely simplified interpretation of the findings. Smad2 is a signal molecule that can be phosphorylated by at least 4 different receptors in response to different ligands, such as angiotensin II, myostatin, TGF- $\beta 1,-2$ and -3 and activin- $\mathrm{A}^{45}$. So increased psmad 2 is not evidence of increased TGF- $\beta$ activity, as has been suggested ${ }^{46}$. A more logical candidate for the increased $\mathrm{p}$-smad 2 and for the effect of losartan is angiotensin II, through the effect of the drug on angiotensin II receptor type $1^{42,47,48}$. The aggravating effect that has been found for inflammation in Marfan syndrome may be a result of local production of activin-A by mast cells and macrophages ${ }^{49}$.

Clinical trials with losartan have shown variable results. Studies in the Netherlands ${ }^{50}$ and the USA ${ }^{51}$ showed a significant reduction in growth of aortic diameter in Marfan patients that used losartan, compared to patients that used beta blockers, whereas this was not confirmed by studies in France ${ }^{52}$ and Spain $^{53}$. A meta analysis of clinical trials with losartan, comprising 1398 subjects, revealed no significant effect of losartan ${ }^{54}$.

We re-analyzed the data of the Netherlands study after grouping the patients based on effect of the FBN1 mutations on the protein ${ }^{42}$. The groups were defined as described above The HN group comprised $35 \%$ of the patients and the DN group $65 \%$.

Interestingly, a significant effect of losartan was found only in the HN group $(\mathrm{p}<0.001)$. This is in contrast with the idea that TGF- $\beta$ is responsible for the growth of aortic diameter in Marfan patients. It has been assumed that TGF- $\beta$ is easily released from mutant fibrillin 1 , causing activation of the TGF- $\beta$ receptors and smad2 phosphorylation, which supposedly could be inhibited by a side effect of losartan. If that were the case, losartan would be only effective in the DN group, whereas we demonstrated the opposite. Our study so far has not been confirmed by others, probably because in the other clinical trials no complete mutation analysis of all patients had been performed and no fibroblasts were available for RNA studies that are necessary to prove NMD. The discrepancy in the results of the clinical trials might be a result of distribution of $\mathrm{DN}$ and $\mathrm{HN}$ mutations. A relatively small number of $\mathrm{HN}$ mutations in the population would lead to a lack of statistical significance in the overall results.

We concluded from the finding that losartan is only effective in patients with HN mutations, that a more likely explanation for the effect of losartan is through angiotensin $\mathrm{II}^{42}$. HN mutations lead to a reduced production of fibrillin 1, which will cause a lower ratio of fibrillin to elastin and increased extensibility of the aorta. This will cause low blood pressure, which will induce activation of angiotensin II. This will cause phosphorylation of smad 2 and- 3 and changes in gene regulation, affecting the balance between proliferation and differentiation of smooth muscle cells, which is ultimately the cause of growth of the aortic diameter. Losartan, in this scenario, exerts an effect by inhibiting the angiotensin II receptor type 1, as it is supposed to do.

We have, as yet, no working hypothesis that explains the growth of aortic diameter in patients with a DN mutation.

\section{CONCLUSIONS}

Marfan syndrome is an under-diagnosed condition in East Asia. The awareness of this condition is very low, even among health care professionals. Mutation testing of FBN1 is important for 1) Genetic counseling (recurrence risk; options for prevention). 2) Presymptomatic diagnosis in families to assess individuals at risk. 3) Medication: the effect of losartan probably depends on the type of causative mutation in FBN1 (HN or DN). Therefore, mutation testing may be important in choice of therapy.

Further studies are needed to elucidate the effect of losartan, especially in relation to the type of mutation. The interpretation of data from losartan research is obscured by the so-called TGF- $\beta$ paradox in aortic 
aneurysms. This paradox is the result of oversimplified interpretation of observations concerning $\operatorname{smad} 2 / 3$ phosphorylation. There is no need for a paradox if the data are interpreted correctly.

\section{REFERENCES}

1. Marfan, AB. Un cas de déformation congénitale des quartre membres, plus prononcée aux extrémitiés, caractérisée par l'allongement des os avec un certain degré d'amincissement. Bulletins et memoires de la Société medicale des hôspitaux de Paris. 1896;13 (3rd series): 220-226.

2. Groth KA, Stochholm K, Hove H, Andersen NH, Gravholt CH. Causes of Mortality in the Marfan Syndrome(from a Nationwide Register Study). Am J Cardiol. 2018 Oct 1;122(7):1231-1235. doi: 10.1016/j.amjcard.2018.06.034. Epub 2018 Jul 21.

3. Ergoren MC, Turkgenc B, Terali K, Rodoplu O, Verstraeten A, Van Laer L, Mocan G, Loeys B, Tetik O, Temel SG. Identification and characterization of a novel FBN1 gene variant in an extended family with variable clinical phenotype of Marfan syndrome. Connect Tissue Res. 2018 May 28:1-9. doi: 10.1080/03008207.2018.1472589. [Epub ahead of print]

4. Aalberts JJ, Schuurman AG, Pals G, Hamel BJ, Bosman G, Hilhorst-Hofstee Y, BargeSchaapveld DQ, Mulder BJ, van den Berg MP, van Tintelen JP. Recurrent and founder mutations in the Netherlands: Extensive clinical variability in Marfan syndrome patients with a single novel recurrent fibrillin-1 missense mutation. Neth Heart J. 2010 Feb;18(2):85-9.

5. Li Y, Xu J, Chen M, Du B, Li Q, Xing Q, Zhang Y. A FBN1 mutation association with different phenotypes of Marfan syndrome in a Chinese family. Clin Chim Acta. 2016 Sep 1;460:102-6. doi: 10.1016/j.cca.2016.06.031. Epub 2016 Jun 25.

6. Beighton P, de Paepe A, Danks D, Finidori G, Gedde-Dahl T, Goodman R, Hall JG, Hollister DW, Horton W, McKusick VA, Opitz JM, Pope FM, Pyeritz RE, Rimoin DL, Sillence D, Spranger JW, Thompson E, Tsipouras P, Viljoen D, Winship I, Young James I, Reynolds F. International nosology of heritable disorders of connective tissue, Berlin, 1986. Am J Med Genet. 1988 Mar;29(3):581-94. doi:10.1002/ajmg.1320290316

7. De Paepe A1, Devereux RB, Dietz HC, Hennekam RC, Pyeritz RE. Revised diagnostic criteria for the Marfan syndrome. Am J Med Genet. 1996 Apr 24;62(4):417-26. doi: 10.1136/jmg.2009.072785.

8. Loeys BL, Dietz HC, Braverman AC, Callewaert BL, De Backer J, Devereux RB, Hilhorst-Hofstee Y, Jondeau G, Faivre L, Milewicz DM, Pyeritz RE, Sponseller PD, Wordsworth P, De Paepe AM. The revised Ghent nosology for the Marfan syndrome. J Med Genet. 2010 Jul;47(7):476-85. doi: 10.1136/jmg.2009.072785.
9. Attanasio M, Pratelli E, Porciani MC, Evangelisti L, Torricelli E, Pellicanò G, Abbate R, Gensini GF, Pepe G. Dural ectasia and FBN1 mutation screening of 40 patients with Marfan syndrome and related disorders: role of dural ectasia for the diagnosis. Eur J Med Genet. 2013 Jul;56(7):35660. doi: 10.1016/j.ejmg.2013.04.006. Epub 2013 May 15.

10. Franken R, den Hartog AW, van de Riet L, Timmermans J, Scholte AJ, van den Berg MP, de Waard V, Zwinderman AH, Groenink M, Yip JW, Mulder BJ. Clinical features differ substantially between Caucasian and Asian populations of Marfan syndrome. Circ J. 2013;77(11):2793-8. Epub 2013 Aug 29.

11. Yoo EH, Woo H, Ki CS, Lee HJ, Kim DK, Kang IS, Park P, Sung K, Lee CS, Chung TY, Moon JR, Han H, Lee ST, Kim JW. Clinical and genetic analysis of Korean patients with Marfan syndrome: possible ethnic differences in clinical manifestation. Clin Genet. 2010 Feb;77(2):17782. doi: 10.1111/j.1399-0004.2009.01287.x. Epub 2009 Oct 23. Erratum in: Clin Genet. 2010 Nov;78(5):505. doi: 10.1111/j.13990004.2009.01287.x. Epub 2009 Oct 23. Erratum in: Clin Genet. 2010 Nov;78(5):505.

12. Faivre L, Collod-Beroud G, Callewaert B, Child A, Loeys BL, Binquet C, Gautier E, Arbustini E, Mayer K, Arslan-Kirchner M, Kiotsekoglou A, Comeglio P, Grasso M, Beroud C, Bonithon-Kopp C, Claustres M, Stheneur C, Bouchot O, Wolf JE, Robinson PN, Adès L, De Backer J, Coucke P, Francke U, De Paepe A, Boileau C, Jondeau G. Pathogenic FBN1 mutations in 146 adults not meeting clinical diagnostic criteria for Marfan syndrome: further delineation of type 1 fibrillinopathies and focus on patients with an isolated major criterion. Am J Med Genet A. 2009 May;149A(5):854-60 doi: 10.1002/ajmg.a.32809.

13. Dietz HC Cutting GR Pyeritz RE . Marfan syndrome caused by a recurrent de novo missense mutation in the fibrillin gene. . Nature. 1991;352:337-339. doi: 10.1038/352337a0

14. Loeys B, De Backer J, Van Acker P, Wettinck K, Pals G, Nuytinck L, Coucke P, De Paepe A. Comprehensive molecular screening of the FBN1 gene favors locus homogeneity of classical Marfan syndrome. Hum Mutat. 2004 Aug;24(2):140-6. doi: 10.1002/humu.20070

15. Teixeira LV, Lezirovitz K, Pereira LV, Perez AB. Candidate gene linkage analysis indicates genetic heterogeneity in Marfan syndrome. Braz J Med Biol Res. 2011 Aug;44(8):793-800.

16. Groth KA, Hove H, Kyhl K, Folkestad L, Gaustadnes M, Vejlstrup N, Stochholm K, Østergaard JR, Andersen NH, Gravholt CH. Prevalence, incidence, and age at diagnosis in Marfan Syndrome. Orphanet J Rare Dis. 2015 Dec 2;10:153. doi: 10.1186/s13023-015-0369-8.

17. Penpattharakul W, Pithukpakorn M. Revised Ghent Criteria is Comparable to Original Diagnostic Criteria for Marfan Syndrome with Increased Ability to Clinically Diagnose Related 
Disorders. J Med Assoc Thai. 2016 Jan;99(1):349.

18. de Vries BB, Pals G, Odink R, Hamel BC. Homozygosity for a FBN1 missense mutation: clinical and molecular evidence for recessive Marfan syndrome. Eur J Hum Genet. 2007 Sep;15(9):930-5. doi: 10.1038/sj.ejhg.5201865

19. Van Dijk FS, Hamel BC, Hilhorst-Hofstee Y, Mulder BJ, Timmermans J, Pals G, Cobben JM. Compound-heterozygous Marfan syndrome. Eur J Med Genet. 2009 Jan-Feb;52(1):1-5. doi: 10.1016/j.ejmg.2008.11.004. Epub 2008 Nov 27.

20. Isogai Z, Ono RN, Ushiro S, Keene DR, Chen Y, Mazzieri R, Charbonneau NL, Reinhardt DP, Rifkin DB, Sakai LY. Latent transforming growth factor beta-binding protein 1 interacts with fibrillin and is a microfibril-associated protein. $\mathbf{J}$ Biol Chem. 2003 Jan 24;278(4):2750-7. doi: 10.1074/jbc.M209256200

21. Davis MR1, Summers KM. Structure and function of the mammalian fibrillin gene family: implications for human connective tissue diseases. Mol Genet Metab. 2012 Dec;107(4):635-47. doi: 10.1016/j.ymgme.2012.07.023. Epub 2012 Aug 3.

22. Hubmacher D, Apte SS. ADAMTS proteins as modulators of microfibril formation and function. Matrix Biol. 2015 Sep;47:34-43. doi: 10.1016/j.matbio.2015.05.004. Epub 2015 May 7.

23. Gabriel LA Wang LW Bader H. ADAMTSL4, a secreted glycoprotein widely distributed in the eye, binds fibrillin- 1 microfibrils and accelerates microfibril biogenesis. Invest Ophthalmol Vis Sci . 2012;53:461-469. doi: 10.1167/iovs.10-5955.

24. Beroud C Collod-Beroud G Boileau C Soussi T Junien C. UMD (Universal mutation database): a generic software to build and analyze locusspecific databases. Hum Mutat . 2000;15:86-94. doi:10.1002/(SICI)1098-

004(200001)15:1<86::AID-UMU16>3.0.CO;2-4

25. Hilhorst-Hofstee Y, Hamel BC, Verheij JB, Rijlaarsdam ME, Mancini GM, Cobben JM, Giroth C, Ruivenkamp CA, Hansson KB, Timmermans J, Moll HA, Breuning MH, Pals G. The clinical spectrum of complete FBN1 allele deletions. Eur J Hum Genet. 2011 Mar;19(3):24752. doi: 10.1038/ejhg.2010.174. Epub 2010 Nov 10.

26. Furtado LV, Wooderchak-Donahue W, Rope AF, Yetman AT, Lewis T, Plant P, Bayrak-Toydemir $P$. Characterization of large genomic deletions in the FBN1 gene using multiplex ligationdependent probe amplification. BMC Med Genet. 2011 Sep 21;12:119. doi: 10.1186/1471-2350-12119.

27. Mátyás G, Alonso S, Patrignani A, Marti M, Arnold E, Magyar I, Henggeler C, Carrel T, Steinmann B, Berger W. Large genomic fibrillin1 (FBN1) gene deletions provide evidence for true haploinsufficiency in Marfan syndrome. Hum Genet. 2007 Aug;122(1):23-32. doi: 10.1007/s00439-007-0371-X

28. Yang H, Ma Y, Luo M, Zhao K, Zhang Y, Zhu G, Sun $X$, Luo F, Wang L, Shu C, Zhou Z.
Identification of gross deletions in FBN1 gene by MLPA. Hum Genomics. 2018 Oct 4;12(1):46. doi: 10.1186/s40246-018-0178-y.

29. Dordoni C, Ciaccio C, Santoro G, Venturini M, Cavallari U, Ritelli M, Colombi M. Marfan syndrome: Report of a complex phenotype due to a $15 q 21.1$ contiguos gene deletion encompassing FBN1, and literature review. Am J Med Genet A. 2017 Jan;173(1):200-206. doi: 10.1002/ajmg.a.37975. Epub 2016 Sep 12.

30. Schouten JP, McElgunn CJ, Waaijer R, Zwijnenburg D, Diepvens F, Pals G. Relative quantification of 40 nucleic acid sequences by multiplex ligation-dependent probe amplification. Nucleic Acids Res. 2002 Jun 15;30(12):e57

31. Knott V, Downing AK, Cardy CM, Handford P. Calcium binding properties of an epidermal growth factor-like domain pair from human fibrillin-1. J Mol Biol. 1996 Jan 12;255(1):22-7.

32. iCn3D [Internet]. Bethesda (MD): National Library of Medicine (US), National Center for Biotechnology Information. 2016 - available from:

https://www.ncbi.nlm.nih.gov/structure/icn3d/icn 3d.html. .

33. Hilhorst-Hofstee Y, Rijlaarsdam ME, Scholte AJ, Swart-van den Berg M, Versteegh MI, van der Schoot-van Velzen I, Schäbitz HJ, Bijlsma EK, Baars MJ, Kerstjens-Frederikse WS, Giltay JC, Hamel BC, Breuning MH, Pals G. The clinical spectrum of missense mutations of the first aspartic acid of cbEGF-like domains in fibrillin-1 including a recessive family. Hum Mutat. 2010 Dec;31(12):E1915-27. doi: 10.1002/humu.21372.

34. Exome Aggregation Consortium. Analysis of protein-coding genetic variation in 60,706 humans .http://dx.doi.org/10.1101/030338. doi: 10.1038/nature19057.

35. Bresters D, Nikkels PG, Meijboom EJ, Hoorntje TM, Pals G, Beemer FA. Clinical, pathological and molecular genetic findings in a case of neonatal Marfan syndrome. Acta Paediatr. 1999 Jan;88(1):98-101.

36. ter Heide H, Schrander-Stumpel CT, Pals G, Delhaas T. Neonatal Marfan syndrome: clinical report and review of the literature. Clin Dysmorphol. 2005 Apr;14(2):81-4.

37. Baudhuin LM, Kotzer KE, Lagerstedt SA. Increased frequency of FBN1 truncating and splicing variants in Marfan syndrome patients with aortic events. Genet Med. 2015 Mar;17(3):177-87. doi: 10.1038/gim.2014.91. Epub 2014 Aug 7.

38. den Hartog AW, Franken R, Zwinderman AH, Timmermans J, Scholte AJ, van den Berg MP, de Waard V, Pals G, Mulder BJ, Groenink M. The risk for type $\mathrm{B}$ aortic dissection in Marfan syndrome. J Am Coll Cardiol. 2015 Jan 27;65(3):246-54. doi: 10.1016/j.jacc.2014.10.050.

39. Franken R, Groenink M, de Waard V, Feenstra HM, Scholte AJ, van den Berg MP, Pals G, Zwinderman AH, Timmermans J, Mulder BJ. Genotype impacts survival in Marfan syndrome. 
Eur Heart J. 2016 Nov 14;37(43):3285-3290. doi: 10.1093/eurheartj/ehv739

40. Franken R, Teixido-Tura G, Brion M, Forteza A, Rodriguez-Palomares J, Gutierrez L, Garcia Dorado D, Pals G, Mulder BJ, Evangelista A. Relationship between fibrillin-1 genotype and severity of cardiovascular involvement in Marfan syndrome. Heart. 2017 Nov;103(22):1795-1799. doi: 10.1136/heartjnl-2016-310631. Epub 2017 May 3.

41. den Hartog AW, Franken R, van den Berg MP, Zwinderman AH, Timmermans J, Scholte AJ, de Waard V, Spijkerboer AM, Pals G, Mulder BJ, Groenink M. The effect of losartan therapy on ventricular function in Marfan patients with haploinsufficient or dominant negative FBN1 mutations. Neth Heart J. 2016 Nov;24(11):675681. doi: 10.1007/s12471-016-0905-8

42. Franken R, den Hartog AW, Radonic T, Micha D, Maugeri A, van Dijk FS, Meijers-Heijboer HE, Timmermans J, Scholte AJ, van den Berg MP, Groenink M, Mulder BJ, Zwinderman AH, de Waard V, Pals G. Beneficial Outcome of Losartan Therapy Depends on Type of FBN1 Mutation in Marfan Syndrome. Circ Cardiovasc Genet. 2015 Apr;8(2):383-8.

doi:10.1161/CIRCGENETICS.114.000950. Epub 2015 Jan 22

43. Habashi JP, Judge DP, Holm TM, Cohn RD, Loeys BL, Cooper TK, Myers L, Klein EC, Liu G, Calvi C, Podowski M, Neptune ER, Halushka MK, Bedja D, Gabrielson K, Rifkin DB, Carta L, Ramirez F, Huso DL, Dietz HC. Losartan, an AT1 antagonist, prevents aortic aneurysm in a mouse model of Marfan syndrome. Science. 2006 Apr 7;312(5770):117-21.doi:

$10.1126 /$ science. 1124287

44. Loeys BL, Chen J, Neptune ER, Judge DP, Podowski M, Holm T, Meyers J, Leitch CC, Katsanis N, Sharifi N, Xu FL, Myers LA, Spevak PJ, Cameron DE, De Backer J, Hellemans J, Chen Y, Davis EC, Webb CL, Kress W, Coucke P, Rifkin DB, De Paepe AM, Dietz HC. A syndrome of altered cardiovascular, craniofacial, neurocognitive and skeletal development caused by mutations in TGFBR1 or TGFBR2. Nat Genet. 2005 Mar;37(3):275-81 DOI: 10.1038/ng1511

45. Akhurst RJ. The paradoxical TGF- $\beta$ vasculopathies. Nat Genet. 2012 Jul 27;44(8):8389.doi: 10.1038/ng.2366

46. Loeys BL. Angiotensin receptor blockers: a panacea for Marfan syndrome and related disorders? Drug Discov Today. 2015 Feb;20(2):262-6.doi: 10.1016/j.drudis.2014.09.022

47. Franken R, Radonic T, den Hartog AW, Groenink M, Pals G, van Eijk M, Lutter R, Mulder BJ, Zwinderman AH, de Waard V; COMPARE study group.. The revised role of TGF- $\beta$ in aortic aneurysms in Marfan syndrome. Neth Heart J. 2015 Feb;23(2):116-21 doi: 10.1007/s12471-0140622-0.
48. van Dijk FS, Meijers-Heijboer H, Pals G. Angiotensin II blockade in Marfan's syndrome. N Engl J Med. 2008 Oct 16;359(16):1733

49. Radonic T, de Witte P, Groenink M, de Waard V, Lutter R, van Eijk M, Jansen M, Timmermans J, Kempers M, Scholte AJ, Hilhorst-Hofstee Y, van den Berg MP, van Tintelen JP, Pals G, Baars MJ, Mulder BJ, Zwinderman AH. Inflammation aggravates disease severity in Marfan syndrome patients. PLoS One. 2012;7(3):e32963. doi: 10.1371/journal.pone.0032963. Epub 2012 Mar 30.

50. Groenink M, den Hartog AW, Franken R, Radonic T, de Waard V, Timmermans J, Scholte AJ, van den Berg MP, Spijkerboer AM, Marquering HA, Zwinderman AH, Mulder BJ. Losartan reduces aortic dilatation rate in adults with Marfan syndrome: a randomized controlled trial. Eur Heart J. 2013 Dec;34(45):3491-500 doi: 10.1093/eurheartj/eht334. Epub 2013 Sep 2

51. Lacro RV, Dietz HC, Sleeper LA, Yetman AT, Bradley TJ, Colan SD, Pearson GD, Selamet Tierney ES, Levine JC, Atz AM, Benson DW, Braverman AC, Chen S, De Backer J, Gelb BD, Grossfeld PD, Klein GL, Lai WW, Liou A, Loeys BL, Markham LW, Olson AK, Paridon SM, Pemberton VL, Pierpont ME, Pyeritz RE, Radojewski E, Roman MJ, Sharkey AM, Stylianou MP, Wechsler SB, Young LT, Mahony L; Pediatric Heart Network Investigators. Atenolol versus losartan in children and young adults with Marfan's syndrome. N Engl J Med. 2014 Nov 27;371(22):2061-71. doi: 10.1056/NEJMoa1404731. Epub 2014 Nov 18.

52. Milleron O, Arnoult F, Ropers J, Aegerter P, Detaint D, Delorme G, Attias D, Tubach F, Dupuis-Girod S, Plauchu H, Barthelet M, Sassolas F, Pangaud N, Naudion S, Thomas-Chabaneix J, Dulac Y, Edouard T, Wolf JE, Faivre L, Odent S, Basquin A, Habib G, Collignon P15, Boileau C16, Jondeau G17. Marfan Sartan: a randomized, double-blind, placebo-controlled trial. Eur Heart J. 2015 Aug 21;36(32):2160-6. doi: 10.1093/eurheartj/ehv151. Epub 2015 May 2.

53. Teixido-Tura G, Forteza A, Rodríguez-Palomares J, González Mirelis J, Gutiérrez L, Sánchez V, Ibáñez B, García-Dorado D, Evangelista A. Losartan Versus Atenolol for PreventionÂ of Aortic Dilation in Patients With Marfan Syndrome. J Am Coll Cardiol. 2018 Oct 2;72(14):1613-1618 doi: 10.1016/j.jacc.2018.07.052.

54. Gao L, Chen L, Fan L, Gao D, Liang Z, Wang R, $\mathrm{Lu} \mathrm{W}$. The effect of losartan on progressive aortic dilatation in patients with Marfan's syndrome: a meta-analysis of prospective randomized clinical trials. Int J Cardiol. 2016 Aug 15;217:190-4. doi: 10.1016/j.ijcard.2016.04.186. Epub 2016 May 4. 